\title{
REFLEKSI PEMBELAJARAN MATEMATIKA SMK MUHAMMADIYAH 1 PONOROGO PADA MATERI PERSAMAAN DAN PERTIDAKSAMAAN LINEAR MUTLAK
}

\author{
Sumaji $^{1}$, Wahyudi ${ }^{2}$ \\ ${ }^{1,2}$ Universitas Muhammadiyah Ponorogo, Jln. Budi Utomo No.10, Ponorogo, Jawa Timur \\ majisutoyo@gmail.com
}

\begin{abstract}
This study aims to describe the results of reflection on mathematics learning in class $\mathrm{X}$ students at SMK Muhammadiyah 1 Ponorogo. This is done to find out in more detail the description of mathematics learning that has been done. This research was conducted because from the results of observations and discussions with the mathematics teacher and the principal, the students underestimated mathematics learning in SMK in particular because the progress in the future only works so that the existence of learning is not considered and student activity needs to be considered. Thus, there needs to be a learning design that is more attractive and provides more treatment to students. This research method is descriptive qualitative research. The subjects of this study were 25 students of class X majoring in motorcycle engineering. Material The results of this study indicate that using discovery learning, sorogan, and assisted power point-based video media can generate activity, enthusiasm for learning in students, and hone students' conceptual skills. This is shown by the students being more enthusiastic about learning mathematics well, solving problems thoroughly, and being able to hone their mathematical conceptual skills. This can happen because students are involved (actively) in learning. Student activeness increases to $80 \%$ of students because they are involved in learning.
\end{abstract}

Keyword: Active, discovery learning, sorogan, media

\begin{abstract}
Abstrak
Penelitian ini bertujuan untuk mendeskripsikan hasil refleksi pembelajaran matematika siswa kelas $\mathrm{X}$ di SMK Muhammadiyah 1 Ponorogo. Hal ini dilakukan untuk mengetahui lebih detail gambaran pembelajaran matematika yang telah dilakukan. Penelitian ini dilakukan karena dari hasil observasi dan diskusi dengan guru matematika bersama kepala sekolah, pembelajaran matematika di SMK khususnya, dipandang sebelah mata oleh siswa, karena progres ke depan hanyalah bekerja, sehingga eksistensi belajar tidak diperhatikan dan keaktifan siswa perlu diperhatikan. Dengan demikian, perlu adanya desain pembelajaran yang lebih menarik dan memberikan perlakuan lebih kepada siswa. Metode penelitian ini adalah penelitian deskriptif kualitatif. Subjek Penelitian ini adalah 25 siswa kelas X jurusan teknik sepeda motor. Materi Hasil penelitian ini menunjukkan bahwa dengan menggunakan metode pembelajaran discovery learning, sorogan, dan berbantuan media video berbasis power point mampu menimbulkan keaktifan, semangat belajar dalam diri siswa, dan mengasah kemampuan konsep siswa. Hal ini ditunjukkan dari siswa lebih antusias mengikuti pembelajaran matematika dengan baik, menyelesaikan soal dengan tuntas, dan mampu mengasah kemampuan konsep matematikanya. Hal ini dapat terjadi karena siswa diikutsertakan (aktif) dalam pembelajaran. Keaktifan siswa meningkat menjadi 80\% siswa karena dilibatkan dalam pembelajaran.
\end{abstract}

Kata Kunci: aktif, discovery learning, sorogan, media

\section{PENDAHULUAN}

Dalam proses pembelajaran sangat perlu diperhatikan adalah pemilihan dan penggunakan metode, model, dan media pembelajaran dengan tepat. Selain itu, peran siswa yakni keaftikan siswa juga sangat perlu diperhatikan. Hal ini tidak lain bertujuan untuk menjadikan proses pembelajaran yang bermakna. Menurut Faslah (2011) ketika siswa dapat menghubungkan satu konsep dengan konsep lainnya, maka pembelajaran yang dilakukan menjadi bermakna. Siswa akan mampu menghubungkan antar suatu konsep bergantung pada banyaknya pengalaman konsep yang dimiliki. Siswa akan mudah memahami sebuah konsep apabila siswa dapat mengalami, merasakan dan konsep 
tersebut tidak abstrak. Tokoh psikolog pendidikan yaitu Ausubel mengatakan juga bahwa Pembelajaran bermakna merupakan suatu proses mengaitkan informasi baru pada konsep-konsep relevan yang terdapat dalam struktur kognitif seseorang. Hal ini menjadi teori pembelajaran yang menjadi dasar dalam pembelajaran kooperatif.

Menurut Rofiq (2010) Pembelajaran kooperatif merupakan metode belajar yang dilaksanakan dengan bekerja sama antar siswa, sehingga nantinya siswa tidak semata mencapai kesuksesan secara individual atau saling mngalahakan antar siswa. Namun mereka juga bisa membantu teman belajarnya yang berkemampuan di bawah standar minimum, dengan demikian tumbuhlah jiwa sosial dalam diri siswa. Hal ini didukung oleh Prakoso, dkk (2015) dari hasil penelitian diketahui bahwa dengan menerapkan model pembelajaraan kooperatif tipe discovery learning mampu meningkatkan aktifitas dan hasil belajar siswa. Berdasakan eksperimen yang dilakukan Tampubolon (2020) menunjukkan bahwa model pembelajaran tipe discovery learning berpengaruh positif dan signifikan terhadap aktivitas dan hasil belajar. Dengan demikian, peneliti memilih salah satunya metode pembelajaran kooperatif tipe discovery learning untuk digunakan sesuai dengan permasalahan di kelas sesuai dengan hasil observasi.

Dari hasil observasi di kelas X jurusan teknik sepeda motor di SMK Muhammadiyah 1 Ponorogo diketahui bahwa siswa pasif dalam pembelajaran matematika. Hal ini dibuktikan dengan adanya siswa tidur saat pembelajaran matematika berlangsung. Terdapat juga siswa diam-diam bermain handphone yang diletakkan di dalam tas, ada juga siswa berbicara dengan teman sebangku dengan suara yang pelan, dan lain sebagainya. Dari 25 siswa kelas X jurusan teknik sepeda motor hanya 8\% yang mengikuti proses pembelajaran matematika. Selain itu, berdasarkan wawancara dengan guru matematika, siswa khususnya sekolah di SMK, pelajaran matematika seperti pelajaran yang tidak penting bagi siswa. Hal ini ditunjukkan dari siswa yang dari awal tidak pernah mengikuti proses pembelajaran matematika dengan baik. Mereka hadir di kelas saja sudah untung. Sedangkan berdasarkan observasi di kelas saat guru mengajar, model pembelajaran yang digunakan belum melibatkan peran aktif siswa yang lebih. Hal ini ditunjukkan guru matematika menggunakan metode pembelajaran konvensional.

Menurut Nella Kresma (2014) pembelajaran konvensional merupakan pembelajaran tradisional karena menggunakan metode ceramah dalam penyampainya. Guru mendominasi kelas sehingga siswa akan merasa jenuh jika terus-menerus dijelaskan oleh guru menggunakan metode ceramah, siswa hanya mendengarkan penjelasan guru tanpa adanya aktifitas timbal balik dari siswa. Dengan demikian, dapat diketahui bahwa pembelajaran konvensional yang juga dilakukan di SMK Muhammadiyah 1 Ponorogo membuat siswa jenuh, dan akhirnya proses pembelajaran matematika kurang efisien. Berdasarkan paparan di atas, peneliti akan mendeskripsikan hasil refleksi dari pembelajaran matematika telah dilakukan di kelas $\mathrm{X}$ jurusan teknik sepeda motor SMK Muhammadiyah 1 Ponorogo. Hal ini bertujuan untuk memberikan gambaran lebih lanjut mengenai pembelajaran matematika di SMK Muhammadiyah 1 Ponorogo. 
Penelitian ini dilakukan di kelas $\mathrm{X}$ dengan maksud belum dibebani jadwal magang dari pihak sekolah. Siswa kelas X belum terkontaminasi/dipengaruhi oleh siswa kelas XI, maupun kelas XII. Pemilihan kelas $\mathrm{X}$ ini juga dari pertimbangan dan rekomendasi guru sekolah. Sedangkan materi persamaan dan pertidaksamaan nilai mutlak linear digunakan sebagai materi penelitian karena ini merupakan materi kedua setelah materi eksponensial dan logaritma. Sehingga ini sangat tepat sekali digunakan untuk melakukan refleksi pembelajaran matematika karena benar-benar akan mengetahui yang sebenarnya tentang karakteristik siswa dalam mengikuti pembelajaran matematika. Dengan ini, dapat diketahui bahwa bagaimana peran siswa saat pembelajaran berlangsung. Dengan demikian, ini menjadi bahan evaluasi pembelajaran matematika untuk menjadikan pembelajaran matematika yang ebih efektif.

\section{METODE}

Penelitian ini merupakan penelitian kualitatif deskriptif. Menurut Anggito \& Setiawan (2018) penelitian kualitatif merupakan penelitian yang menekankan pada pemahaman mengenai masalahmasalah dalam kehidupan sosial berdasarkan kondisi realitas atau natural setting yang holistis, kompleks, dan rinci. Penelitian kualitatif dilakukan dengan karakteristik yang mendespriksikan suatu keadaan yang sebenarnya atau fakta, tetapi laporan yang dibuat bukan laporan sekedar suatu kejadian tanpa suatu interpretasi ilmiah. Kemudian, penelitian kualitatif bersifat deskriptif, peneliti harus mendekripsikan suatu objek, fenomena, atau setting sosial yang ditaungkan dalam tulisan yang bersifat naratif.

Sedangkan menurut Gunawan (2013) penelitian kualitatif ini mengembangkan suatu konsep, pemahaman dari suatu fenomena yang ada kaitannya dengan teori dari bawah. Instrumen penelitian ini adalah peneliti sendiri. Teknik pengumpulan data yang digunakan adalah obervasi, wawancara, dan dokumentasi (dengan mengamati (refleksi) dari proses pembelajaran matematika). Kemudian, setelah data penelitian diperoleh, lalu dilakukan analisis data diantaranya reduksid ata, penyajian data, dan penarikan kesimpulan. Dengan demikian, dapat disimpulkan bahwa penelitian kualitatif deskriptif merupakan penelitian yang membahas suatu masalah dalam kehidupan realitas secara kompleks, holistis dan rinci yang diwujudkan dalam narasi. Alur penelitian secara umum disajikan pada Gambar 1 berikut. 


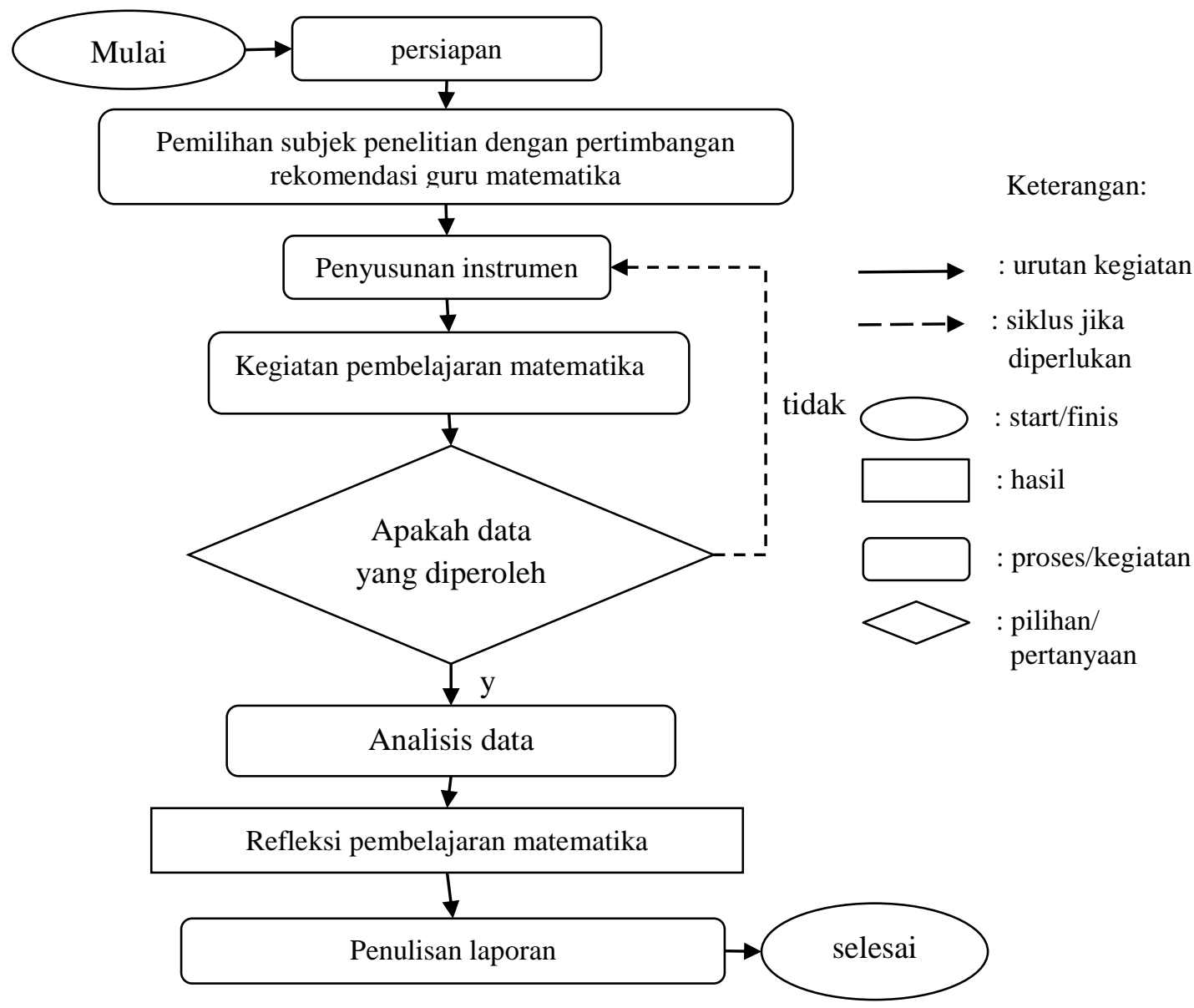

Gambar 1. Diagram Alur Penelitian

\section{HASIL}

Sesuai dengan uraian di pendahuluan, refleksi pembelajaran ini dilakukan mulai dari hasil kegiatan observasi hingga pelaksanaan penelitian. Dari hasil observasi diketahui bahwa hanya $8 \%$ siswa yang mengikuti pembelajaran. Sebelum melakukan penelitian, peneliti berdiskusi dengan kepala sekolah dan guru matematika tentang bagaimana latar belakang masing-masing siswa dan metode apa saja yang sudah digunakan untuk diterapkan dengan karakteristik siswa yang perlu adanya perubahan mental. Sehingga refleksi ini dilakukan hingga pelaksanaan penelitian usai dan melihat bagaimana perubahan yang terjadi pada siswa tersebut.

Dalam penelitian ini, peneliti berjumlah dua orang dengan menerapkan team teaching. Peneliti melakukan model team teaching bertujuan agar proses pembelajaran matematika lebih komplek dalam meneliti dalam berbagai sudut. Menurut Wiradinata (2013) Team teaching adalah terobosan efektif untuk meningkatkan kualitas pendidik secara akseleratif. Masing-masing pendidik tidak akan egois, tapi akan terbuka untuk belajar kepada pendidik lain yang dipandang memiliki kelebihan dan kekurangan. Dengan kolaborasi yang terbentuk dalam team teaching, mereka akan saling melengkapi, menyempurnakan, dan memberi semangat antara satu dengan yang lainnya.

Hal yang berkaitan dengan team teaching juga di dukung oleh pendapatnya Maharani, dkk (2018) yang menyatakan bahwa team teaching merupakan salah satu metode mengajar yang mampu 
memfasilitasi terbentuknya kemampuan interdisipliner secara terintegrasi dan terkoneksi. Team teaching dapat dilakukan oleh lebih dari dua orang guru. Dengan demikian, dapat disimpulkan bahwa team teaching merupakan metode mengajar yang dilakukan oleh pendidik (dosen atau guru) secara team teaching semi atau penuh dengan tujuan meningkatkan kualitas pendidikan dengan melengkapi satu sama lain. Dalam hal ini peneliti melakukan team teaching penuh yaitu 1 peneliti mengajar, dan yang lain membimbing.

Model pembelajaran yang diterpakan oleh peneliti secara team teaching adalah model pembelajaran discovery learning dan sorokan. Untuk melengkapi proses pembelajaran matematika, peneliti menggunakan media power point yang diharapkan mendukung model pembelajaran matematika yang diterapkan. Power point berisikan pendukung instrumen-instrumen pada model pembelajaran discovery learning yaitu media video. Model discovery learning diterapkan di beberapa pertemuan awal. Siswa secara berkelompok untuk mendiskusikan media video yang ditampilkan di power point. Karena materi yang dibahas adalah persamaan dan ketaksamaan linear mutlak, maka media video tersebut mengarah untuk menemukan definisi nilai mutlak. Sehingga sebelum siswa menyelesaikan permasalahan yang berkaitan dengan persamaan dan pertidaksamaan linear mutlak, terlebih siswa mampu memahami dengan menemukan definisi nilai mutlak itu sendiri.

Sebelum proses pembelajaran matematika berlangsung, peneliti selalu melakukan apersepsi yang bertujuan untuk membantu siswa merecall kembali materi-materi yang telah dipahami yang berkaitan dengan materi yang akan dibahas. Dengan demikian, pelajaran matematika yang dibahas akan lebih mudah dari segi manapun seperti halnya konsep matematika.

Untuk memahami maksud video yang diputar oleh peneliti, siswa membutuhkan waktu dua kali pertemuan. Media video yang ditampilkan di power point mengadobsi dari tiga sumber youtube channels. Jumlah video ditampilkan sebanyak 3 macam, dan hanya di ambil sebagian penting saja yang bermaksud supaya siswa mampu mendefinisikan sendiri tentang nilai mutlak. Media video yang dimaksud disini berisikan cuplikan dari tiga youtube channels. Dengan demikian, media video ini hanya sebagian kecil dari tampilan di masing-masing ketiga youtube channels. Berikut ketiga media video yang ditanyakan di power point.

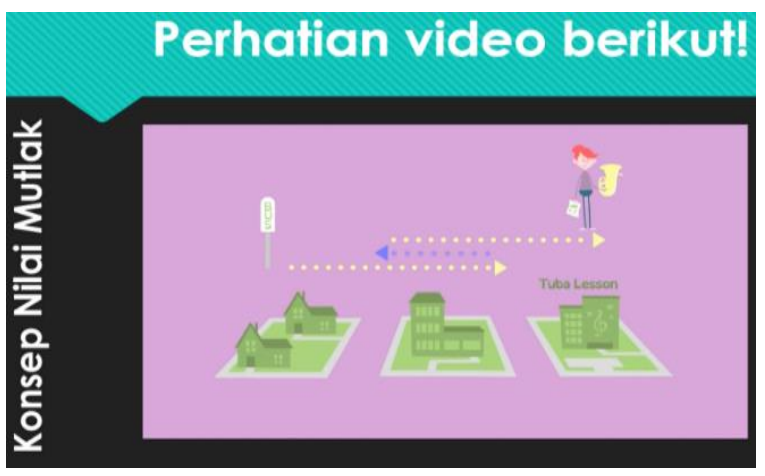

Gambar 2. Media Video Pertama di Power Point

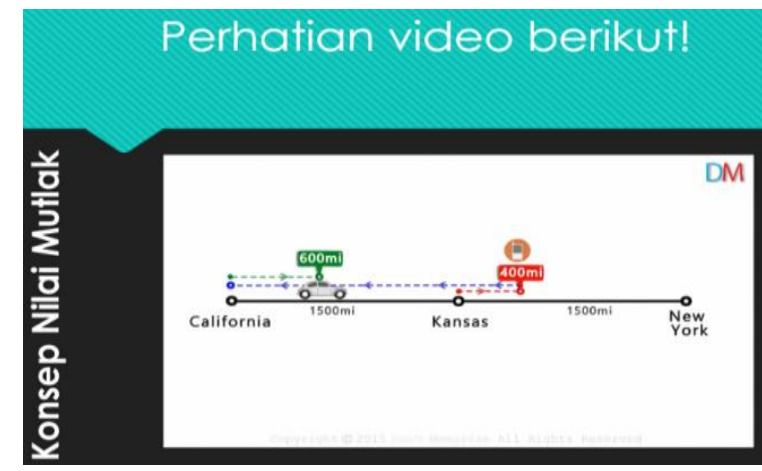

Gambar 3. Media Video Kedua di Power Point 
Pada Gambar 2 menunjukkan media video pertama yang diadobsi sebagian kecil video dari laman youtube https://www.youtube.com/watch?v=wrof6Dw63Es. Media video ini hanya sebagian kecil dari konten youtube tersebut. Isi dari tayangan media video ini digunakan untuk mendukung proses pembelajaran matematika dengan model discovery learning. Pada media video ini menunjukkan gambaran secara umum untuk menentukan atau menemukan definisi nilai mutlak oleh siswa secara berkelompok. Media video pertama ini belum secara detail mengarah ke nilai mutlak, sehingga sebagian besar siswa belum perpikir media video pertama ini mengarah ke nilai mutlak. Dengan demikian, peneliti memberikan tanyangan media video kedua untuk mendukung siswa agar mampu mendefinisikan nilai mutlak ini.

Pada Gambar 3 menunjukkan media video kedua yang berisi sebagian kecil dari cuplikan laman youtube ini https://www.youtube.com/watch?v=zxaT8ArCKjQ. Media video kedua ini dibuat untuk mendukung tayangan media video pertama tadi. Media video kedua ini lebih menunjukkan konsep perjalanan seseorang dengan bantuan pemberian besar perjalanan yang ditempuh. Hal ini dapat diketahui bahwa, media video kedua ini lebih mengarahkan siswa untuk menemukan definisi nilai mutlak sendiri. Setelah melihat tayangan media video kedua ini, siswa mampu menentukan jumlah besaran perjalanan yang ditempuh oleh seseorang. Saat Media video kedua diputar dan diperhatikan oleh semua siswa, peneliti memberikan scaffolding untuk membimbing siswa menemukan definisi nilai mutlak. Setelah meliat media video kedua ini, siswa juga belum mampu menemukan definisi nilai mutlak. Kemudian, siswa akan diberikan media video ketiga dan diharapkan siswa mampu untuk menemukan definisi nilai mutlak. Berikut tampilan media video ketiga yang berada di power point.

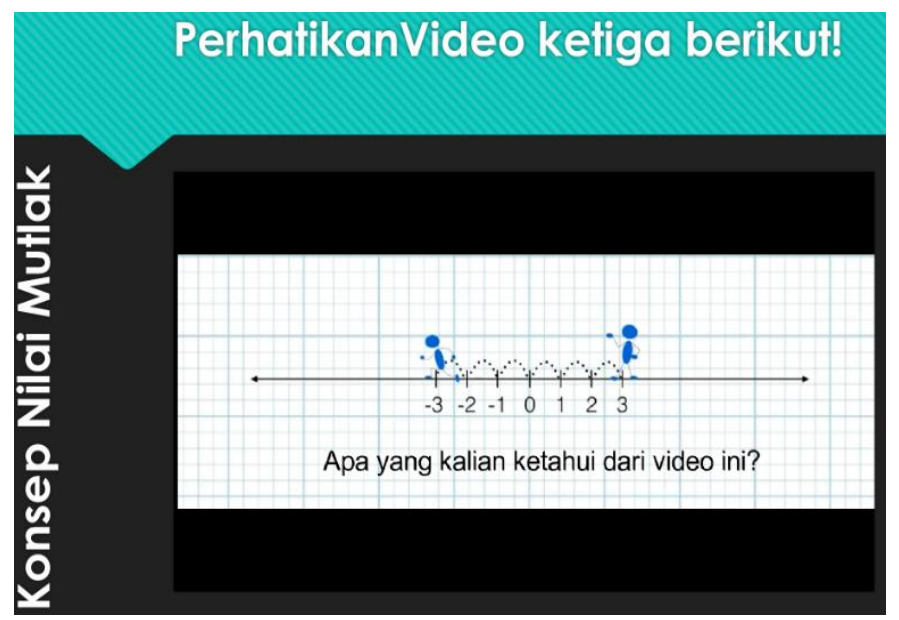

Gambar 4. Media Video Ketiga di Power Point

Pada gambar 4 ini menunjukkan media video ketiga yang mana video ini mengadopsi sebagian isinya yang sesuai dengan penelitian ini dari laman youtube https://www.youtube.com/watch?v=dQCNC97Y-mw. Pada media video ketiga ini sudah lebih mengarah ke definisi nilai mutlak. Setelah melihat media video ketiga, siswa mampu menyebutkan bahwa media video ini berkaitan dengan jarak. Dengan bantuan scaffolding dari peneliti, siswa mampu menemukan definisi nilai mutlak berbantuan power point. Peneliti menggunakan media video 
berbasis power point ini bertujuan untuk mendukung proses pembelajaran matematika dengan model discovery learning.

Dari ketiga media video tersebut dapat diketahui bahwa media video ketiga mendukung media video pertama dan kedua, serta media video kedua lebih menjelaskan secara detail dari media video pertama. Media video berbasis power point ini juga berkaitan dengan kehidupan sehari-hari. Sehingga saat menemukan definisi nilai mutlak, terdapat siswa yang menyebutkan spedometer pada sepada motor, sehingga ini membantu membuka wawasan baru bagi siswa pentingnya belajar matematika dan aktivitas siswa di kelas semakin bagus.

Dengan menerapkan model pembelajaran discovery learning berbantuan media video yang ditampilkan di power point menunjukkan bahwa aktif dalam pembelajar. Menurut Ulfa, dkk (2017) model pembelajaran discovery learning dengan berbantuan video lebih baik daripada pembelajaran konvensional. Siswa mampu menyelesaikan permasalahan yang diberikan secara kelompok ataupun individu. Adapun menurut Maulida, dkk (2018) penggunaan model pembelajaran discovery learning mampu meningkatkan keaktifan siswa dalam pembelajaran matematika. Hal ini juga diperkuat oleh Medianty, dkk (2018) yang menyatakan bahwa dengan melalui model pembelajaran discovery learning berbantuan media video peran guru hanya sebagai fasilitator bukan bersifat teacher centered dan siswa berperan aktif dalam menemukan dan mencari sendiri sesuatu yang dibutuhkan dalam proses pembelajaran. Dengan ini, siswa tidak lagi merasa bosan dalam belajar. Dengan berdasarkan uraian di atas, dapat disimpulkan bahwa dengan menggunakan media video dengan model pembelajaran discovery learning, siswa akan aktif dalam pembelajaran. dengan demikian, itu artinya bahwa siswa diikutsertakan dalam proses pembelajaran matematika, agar pembelajaran matematika lebih baik.

Setelah siswa mampu menemukan definisi nilai mutlak, siswa secara berkelompok mendiskusikan materi persamaan dan pertidaksamaan linear mutlak. Berdasarkan hasil diskusi kelompok, siswa mampu menyelesaikan soal-soal yang berkaitan dengan persamaan dan pertidaksamaan linear mutlak. Peneliti melakukan evaluasi mandiri bagi siswa untuk menyelesaikan soal lain yang masih berkaitan dengan materi. Saat siswa menyelesaikan soal matematika materi tersebut, diketahui bahwa siswa belum mampu menggunakan konsep aljabar dasar dalam menyelesaikan soal materi persamaan dan pertidaksamaan linear mutlak. Dengan demikian, peneliti mengubah model pembelajaran dengan model sorokan. Hal ini dilakukan karena, sebagian besar siswa belum mampu menggunakan konsep aljabar dasar untuk menyelesaikan soal materi persamaan dan pertidaksamaan linear mutlak.

Dalam menerapkan model sorokan, pertama peneliti memberikan soal persamaan linear dengan konsep aljabar dasar. Soal tersebut ditampilkan di power point, hal ini bertujuan agar siswa fokus dalam proses pembelajaran. Setiap siswa secara bergantian wajib menyerahkan hasil tes siswa ke peneliti. Karena peneliti team teaching, maka masing-masing peneliti memberikan scaffolding saat 
setiap siswa berhadapan dengan peneliti secara bergantian. Kegiatan ini berlangsung hingga siswa menyelesaikan soal materi persamaan linear dasar hingga pertidaksamaan nilai mutlak. Aktivitas siswa saat proses pembelajaran ini sangat baik, siswa dituntut untuk bertanggungjawab dalam menyelesaikan soal yang diberikan peneliti. Soal-soal yang diberikan ke siswa berbeda-beda dan diberikan setelah siswa mampu menyelesaikan soal sebelumnya.

Dengan model pembelajaran sorogan ini, siswa mampu dan memahami dengan cara merecall konsep-konsep matematika yang siswa pahamai untuk menyelesaikan soal-soal yang diberikan oleh peneliti. Dengan demikian, dengan model pembelajaran sorogan, siswa mampu mengasah kemampuannya yang berkaitan dengan konsep-konsep matematika. Proses pembelajaran sorogan ini sesuai dengan hasil penelitian yang dilakukan oleh Ningsih (2017) yang menyimpulkan bahwa hasil belajar siswa dengan menerapkan model pembelajaran sorogan dengan team teaching berkategorikan tuntas. Itu artinya bahwa siswa mampu menyelesaikan soal-soal yang diberikan oleh peneliti dengan tuntas, sehingga konsep matematika yang dimiliki siswa juga baik.

Menurut Wakit (2016) pembelajaran sorogan berbantuan tutor sebaya efektif dalam meningkatkan pemahaman konsep. Dengan demikian, dari hasil penelitian ini dapat diketahui bahwa karena siswa belum mampu menyelesaikan soal dengan konsep matematika yang dimiliki siswa, kemudian dengan menerapkan model pembelajaran sorogan, siswa mampu menyelesaikan soal dengan baik, hal ini ditunjukkan dari siswa berkali-kali diberikan soal secara bergantian dan berbeda dengan siswa lainnya, siswa mampu menyelesaikan soal dengan baik. Sehingga model pembelajaran sorogan ini menekankan siswa agar lebih diasah kemampuan konsep matematikanya dan awalnya siswa belum mampu menyelesaikan soal, akhirnya siswa mampu menyelesaikan soal dengan berualang kali sampai materi pertidaksamaan linear mutlak. Adapun peningkatan keaktifan siswa yang mana dalam proses pembelajaran siswa dilibatkan aktif untuk bertanggungjawab dalam belajar dapat dilihat pada Gambar 5 berikut.

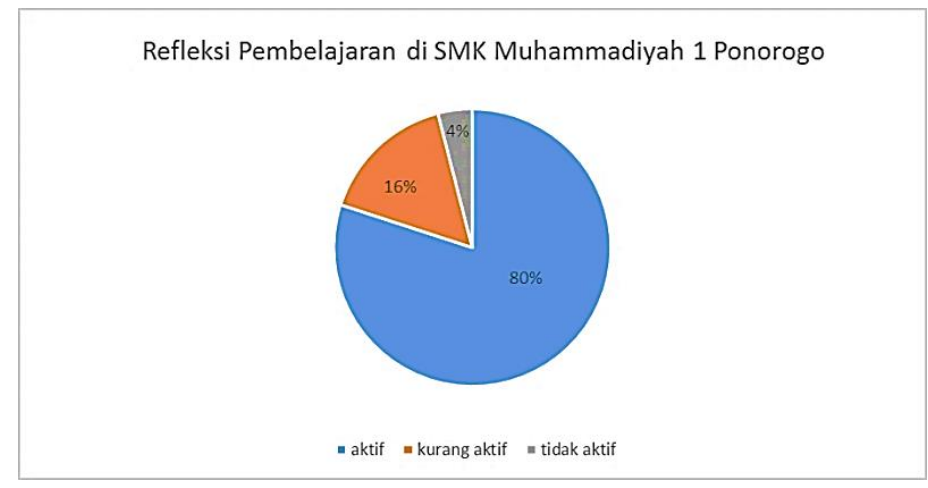

Gambar 5. Hasil Refleksi Pembelajaran Matematika

Kegiatan refleksi pembelajaran matematika dilakukan mulai dari awal kegiatan observasi hingga akhir pelaksanaan penelitian. Hasil ini ditunjukkan dari penerapan model sogoran yang awalnya adalah model discovery learning. Sehingga model pembelajaran ini, disesuikan dengan kondisi siswa yang sebenarnya. Dan hasil evaluasi pembelajaran juga dilakukan disetiap proses 
pembelajaran. Ini bertujuan untuk mengetahui sejauh mana pembelajaran ini dilakukan dengan baik atau perlu adanya perbaikan. Pada Gambar 5 di atas, menunjukkan bahwa adanya keaktifan siswa saat proses pembelajaran. Ini ditunjukkan dari setiap siswa diberikan tanggungjawab penuh untuk mengikuti pembelajaran dengan baik. Sehingga dengan ini siswa akan lebih aktif, nampah bahwa berubahannya hingga menjadi $80 \%$ siswa aktif.

\section{KESIMPULAN}

Dari paparan refleksi dari pembelajaran matematika di atas, dapat diketahui bahwa dengan melibatkan siswa dalam proses pembelajaran matematika, siswa akan aktif dan senang dalam belajar matematika. Terlebih dengan model pembelajaran discovery learning dan sorogan, siswa lebih aktif dengan berbagai ativitas yang dilakukan. Bahkan dengan adanya media video berbasis power point, siswa lebih tertarik dan fokus dalam proses pembelajaran matematika. Siswa juga akhirnya mampu mengasah konsep matematika yang dimilikinya dengan baik. Sehingga belajar matematika akan berarti bagi siswa khususnya siswa SMK. Untuk itu, hal terpenting yang harus diperhatikan adalah keberadaan siswa yang nantinya akan menentukan metode, model, dan media pembelajaran yang sesuai agar menjadi proses pembelajaran matematika yang efektif.

\section{DAFTAR PUSTAKA}

Anggito, A., \& Setiawan, J. (2018). Metodologi Penelitian Kualitatif. Sukabumi: CV Jejak.

Faslah, R. (2011). Pemanfaatan Internet dalam Pengembangan Konsep IPS dan Implikasinya Terhadap Pembelajaran Bermakna. Jurnal Ilmiah Econosains, 9(2), 167-170.

Gunawan, I. (2013). Metode Penelitian Kualitatif. Jakarta: Bumi Aksara.

Maharani, A., Darhim, D., Sabandar, J., \& Herman, T. (2018). Menumbuhkan Kemampuan Disposisi Matematis Melalui PBL-Team Teaching. JNPM (Jurnal Nasional Pendidikan Matematika), 2(2), 197-205.

Maulida, A., Ningsih, M.F., \& Bastian, T. (2018). Pengaruh Model Discovery Learning Terhadap Kemampuan Komunikasi Matematis dan Keaftifan Belajar Siswa SMP. Jurnal Ilmiah Pendidikan Matematika, 6(1), 47-52.

Medianty, S.U., Bahar, A., \& Elvinawati, E. (2018). Penerapan Model Discovery Learning dengan Menggunakan Media Video untuk Meningkatkan Aktivitas Belajar dan Hasil Belajar Siswa Kelas XI IPA 1 SMAN 1 Kota Bengkulu. Alotrop, 2(1), 58-65.

Nella Kresma, E. (2014). Perbandingan Pembelajaran Konvensional dan Pembelajaran Berbasis Masalah Terhadap Titik Jenuh Siswa Maupun Hasil Belajar Siswa Dalam Pembelajaran Matematika. Educatio Vitae, 1(1), 152-164.

Ningsih, L. (2017). Penerapan Metode Sorogan Dipandu dengan Team Teaching pada Model Pembelajaran Langsung Sebagai Alternatif dalam Pembelajaran Matematika. UIN Sunan 
Refleksi Pembelajaran Matematika SMK Muhammadiyah 1 Ponorogo Pada Materi Persamaan dan Pertidaksamaan

Ampel Surabaya.

Prakoso, H.S., Atmadja, N.B., \& Margi, I. K. (2015). Penerapan Model Pembelajaran Kooperatif Tipe Discovery Learning untuk Meningkatkan Aktivitas dan Hasil Belajar Siswa Kelas XI IPS 1 Semester Ganjil Tahun Ajaran 2015/2016 di SMA Laboratorium Undiksha Singaraja. Widya Winayata: Jurnal pendidikan Sejarah, 3(1), 1-13.

Rofiq, M. N. (2010). Pembelajaran Kooperatif (Cooperative Learning) dalam Pengajaran Pendidikan Agama Islam. Jurnal Falasifa, 1(1), 1-14.

Tampubolon, C. A. D. (2020). Pengaruh Model Pembelajaran Kooperatif Tipe Discovery Learning Terhadap Aktivitas dan Hasil Belajar Siswa Kelas XI Pada Mata Pelajaran Ekonom di SMA Negeri 19 Medan Tahun Ajaran 2019/2020. http://repository.uhn.ac.id/handle/123456789/3752

Ulfa, K., Buchori, A., \& Murtianto, Y. H. (2017). Efektivitas Model Guided Discovery Learning untuk Video Pembelajaran dalam Mengetahui Perbedaan Kemampuan Pemecahan Masalah Matematika Siswa. Journal of Mathematics Education, Science and Technology, 2(2), 267-275.

Wakit, A. (2016). Efektivitas Metode Sorogan Berbantuan Tutor Sebaya Terhadap Pemahaman Konsep Matematika. Jurnal Edukasi dan Sains Matematika, 2(1), 1-12.

Wiradinata, D. R. (2013). Meningkatkan Kualitas Perkualiahan melalui Team Teaching. Edunomic: Jurnal Pendidikan Ekonomi, 1(2), 65-81. 